\title{
Considerations on endodontic care in times of SARS COV-2 pandemic
}

\author{
Considerações sobre o atendimento endodôntico \\ em tempos de pandemia SARS CoV-2
}

\author{
Lorenna Mendes Temóteo BRANDT ${ }^{1}$ iD https://orcid.org/0000-0002-4638-5474 \\ Liege Helena Freitas FERNANDES ${ }^{2}$ iD https://orcid.org/0000-0001-6431-7857 \\ Alessandro Leite CAVALCANTI2 ID https://orcid.org/0000-0003-3572-3332
}

\section{ABSTRACT}

The severe acute respiratory syndrome of the new coronavirus, SARS CoV-2, which became a pandemic, was first reported in Wuhan, Hubei, China, in December 2019. It can cause mild symptoms, but in some cases, it can cause serious complications, leading to death. The disease spreads through aerosol droplets and has an estimated incubation period between 2 and 14 days (a period in which the patient has high potential to infect other people). Endodontists have a high risk of exposure to COVID-19 when compared to other health professionals, since most of the work involves the generation of aerosols and care for patients in emergency situations, such as symptomatic irreversible pulpitis, symptomatic apical periodontitis, acute apical abscess and traumatic dental injuries, is imperative. Thus, this critical review addresses considerations about endodontic care in times of pandemic, whose emergencies imply a real need for treatment, as well as the care that must be adopted to minimize risks for both professionals and patients who seek the resolution of their clinical pain conditions.

Indexing terms: Coronavirus. Dentistry. Endodontics.

\section{RESUMO}

A síndrome respiratória aguda grave do novo coronavírus, SARS CoV-2, que se tornou uma pandemia, foi relatada pela primeira vez em Wuhan, Hubei, China em dezembro 2019. Pode acarretar sintomas leves, porém em alguns casos pode provocar graves complicações levando o indivíduo ao óbito. A doença se espalha através de gotículas de aerossol e tem um período de incubação do coronavírus estimado entre 2 e 14 dias (período este no qual o paciente tem alto potencial de infectar outras pessoas). Os endodontistas apresentam alto risco de exposição ao COVID-19 quando comparado a outros profissionais de saúde, pois a maior parte do trabalho envolve a geração de aerossóis e os atendimentos a pacientes em situações emergentes, como pulpite irreversível sintomática, periodontite apical sintomática, abscesso apical agudo e lesões dentárias traumáticas são imperativos. Dessa forma, essa revisão crítica aborda considerações sobre o atendimento endodôntico, nesta época de pandemia, cujas emergências imprimem necessidade real de tratamento, bem como os cuidados que devem ser adotados visando minimizar riscos tanto para o profissional quanto para os pacientes que buscam a resolução dos seus quadros clínicos de dor.

Termos de indexação: Coronavirus. Odontologia. Endodontia.

$\boldsymbol{\nabla} \nabla \boldsymbol{\nabla}$

1 UNIFACISA Centro Universitário, Departamento de Odontologia. Campina Grande, PB, Brasil.

2 Universidade Estadual da Paraíba, Departamento de Odontologia. R. Baraúnas, 351 - Universitário, 58429-500, Campina Grande, Paraíba, Brasil. Correspondence to: Alessandro Leite Cavalcanti. E-mail: <alessandrouepb@gmail.com>.

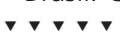

Brandt LMT, Fernandes LHF, Cavalcanti AL. Considerations on endodontic care in times of SARS CoV-2 pandemic. RGO, Rev Gaúch Odontol. 2021;69:e20210026. http://dx.doi.org/10.1590/1981-86372021002620200142 


\section{INTRODUCTION}

The severe acute respiratory syndrome of the new coronavirus - SARS CoV-2 (COVID-19), was first reported in Wuhan, Hubei, China, in December 2019 [1]. Since then it has become a public health crisis worldwide [2], being declared a pandemic by the World Health Organization (WHO) on March 11, 2020. Although COVID-19 infections in humans generally cause mild symptoms in most cases, in some situations, it may cause serious complications, leading to death [3].

The disease spreads through aerosol droplets [4] and has an estimated incubation period of 2 to 14 days [5]. It is known that patients without symptoms or who are during the virus incubation period can infect other people [5].

Thus, the American Dental Association (ADA) and the Centers for Disease Control and Prevention (CDC) recommend to oral health professionals extreme caution and warn them to limit dental work strictly to situations of dental emergencies $[6,7]$, since aerosol is the source of COVID-19 spread, in addition to other viral infections, which puts dentists and other dental professionals on the first line of the risk exposure scale [8]. The aerosol produced by dental practice instruments can remain in the air and surfaces for several hours [9], and although the operator can be unhurt if well protected during therapeutic practice, the air will remain contaminated, representing a risk [10].

Thus, patients with non-urgent oral conditions should temporarily avoid attending the dental office [11]. In addition, as the understanding of this new disease is evolving, dental practices should be prepared to identify possible COVID-19 infection and refer the patient with suspected, confirmed or history of COVID-19 infection to appropriate treatment centers [12].

In this pandemic, it is necessary to reduce faceto-face consultations to decrease the risk of infection, and teledentistry can be an alternative for dentists to investigate the need for treatment and ensure continuity of care $[13,14]$, especially for COVID-19 patients or those suspect to be infected [14]. However, if there is need for treatment, at this epidemic moment, every patient should be considered potentially infected with the virus because the clinical presentations of this disease can be dynamic and therefore, there are chances that dentists will treat some patients with asymptomatic COVID-19 infection, and all dental practices need to review their infection control policies, engineering controls and supplies [12].
Therefore, every patient must be considered potentially infected with this virus, and all dental practices need to review their infection control policies, engineering controls and supplies [12].

In view of the above, this critical review aims to present considerations about dental care in time of pandemic, specifically, endodontic care, whose urgencies imply real need for treatment.

\section{Considerations on dental care in Endodontics}

Studies addressing important aspects of COVID-19 regarding clinical severity, extent and types of transmission, as well as the most appropriate treatment, have been carried out worldwide since the beginning of the disease [4]. Until now, there is no consensus on dental treatment protocols that must be adopted for COVID-19 patients [15].

However, it is imperative that the dentist, especially endodontists, take appropriate measures to keep themselves protected $[2,13]$ and ensure patient health in the dental environment since only protective measures do not guarantee the non-contamination of other patients $[13,16]$.

Endodontists have a higher risk of exposure to COVID-19 when compared to other health professionals since most of the work involves the generation of aerosols and the care of patients with dental pain is imperative [17]. In addition, close and prolonged face-to-face contact between patient and dentist during endodontic treatment creates a high risk for cross-infection $[4,17]$.

Protection guidelines for dental care during the COVID-19 pandemic are being formulated based on grouping patients according to their health condition and considering the risks and benefits of the necessary procedures [18]. Most studies recommend the postponement of elective dental treatment, focusing on emergency care only $[12,19]$, since endodontic infections can cause severe pain and endodontic emergencies are considered an important category of dental emergencies [2].

The possible clinical conditions that constitute endodontic emergencies include symptomatic irreversible pulpitis, symptomatic apical periodontitis, acute apical abscess and traumatic dental injuries [4]. When studying the characteristics of dental emergencies during the COVID-19 epidemic in Wuhan, China, Yu et al. [2] found that only dental emergency cases were referred to the 
hospital during online health consultations. They concluded that most dental emergencies were of endodontic origin (50.6\%), including symptomatic irreversible pulpitis, symptomatic apical periodontitis, acute apical abscess and traumatic dental injuries. Bai et al. [11] observed that the frequency of endodontic emergencies and the proportion of patients with acute pain were significantly higher in 2020 than in the same period in 2019.

Emergency dental care for a positive COVID-19 patient may be necessary and, to date, there is no consensus on dental treatment protocols for an infected patient [15], but the advice is not to provide care in a primary dental environment, since the COVID-19 patient is classified as having a level-three biosafety risk, which means that procedures involving microorganisms can cause serious and / or potentially lethal diseases through the airways [20]. In these cases, the hospital environment is the most appropriate for providing frequent air renewal, reducing the risks to the health of professionals $[15,21]$.

\section{Considerations on suggested protocols}

The Center for Disease Control's recommendation to suspend elective dental procedures and avoid aerosolgenerating procedures faces challenges in the management of patients with endodontic emergencies [22]. However, case by case, some authors drive the service by adopting biosafety measures to reduce risks of contamination by COVID-19 $[12,15,16]$.

Yang et al. [16] and Ather et al. [12] suggest that three simple assessments should become routine. The first and most important is the patient's history, preferably remotely, which can be performed by phone or video call. With this, it is possible to know if the patient has had contact with other infected people or shows symptoms that may suggest COVID-19 infection, or even if he / she has already had the disease.

Then, checking the patient's temperature before entering the dental office, even though it is reported as inaccurate and requires calibration [23]. Finally and most importantly, the performance of a quick test in the office environment to verify whether the patient is infected or not $[12,16]$, because rapid and accurate detection is essential to limit the spread of the virus, in addition to reducing the waiting period, allowing immediate intervention for negative cases [4].
In situations where rapid tests are inconclusive or positive, care should be postponed and the patient referred to the doctor or health care provider for additional tests to confirm that the patient has COVID-19 and to ensure that he / she is properly treated and clinically isolated $[12,16]$. The current standard approach for COVID - 19 screening requires a real-time reverse transcriptase-polymerase chain reaction (rRT-PCR) test. However, according to Sharma et al. [4], this approach depends on high-cost facilities, welltrained staff and generally demands more time.

Studies have shown promising results in testing coronavirus diagnosis through saliva, such as the loopmediated isothermal amplification - LAMP [24,25] and microfluidic RT-PCR devices - Lab-on-a-chip tests [1].

According to Yu et al. [2], reducing care time and controlling exposure to the virus are two relevant ways to reduce the risk of contamination during endodontic treatment. The most recent recommendations regarding the use of personal protective equipment (PPE) for dental emergencies include the use of N95 disposable masks, goggles, disposable gloves and caps, shoe protection, face shields and use of cloaks $[15,19]$. However, in the case of endodontic emergency care for positive COVID-19 patients, the recommendation is total protection for face and eyes against aerosols, through the use of full-face masks with an air purifier, which provides protection five to ten times higher than the N95 mask [15].

Concerning to radiological examination, pretreatment radiographs should be limited to extra-oral techniques only, as intraoral radiography can stimulate vomiting and / or cough reflex [26]. The use of computed tomography is also an alternative that can be considered [2], despite the high cost.

Another recommended preoperative approach is to rinse the patient's mouth with hydrogen peroxide of $1 \%$ and / or povidone-iodine to decrease the viral load in saliva $[18,19]$. The use of $0.12 \%$ digluconate chlorhexidine, in turn, still lacks more robust scientific evidence [18]. The use of dental spittoon in dental care should be avoided (which should be insulated with PVC film), with constant saliva aspiration, preferably with a dental vacuum pump [18].

Isolation barriers such as dykes or rubber sheets should be used during clinical care in endodontics (before the pulp chamber access), because, although they are not able to limit aerosol diffusion by themselves, they can drastically reduce or even eliminate the presence of salivary 
components in the aerosol [2,12]. Moreover, with the rubber dam in place, the tooth can be disinfected with $\mathrm{NaOCl}$, which seems to be efficient against the coronavirus [27].

For vital pulp or pulpitis cases, pulpotomy or pulp capping can be useful in shortening treatment time [2]. In COVID-19 patients, once initial emergency pulpectomy or pulpotomy has been performed, definitive treatment should be postponed until the patient recovers, which must be at least three days after symptoms disappear [7]. However, it may be prudent to postpone this procedure for at least a month [15], since the time during which the virus can remain active in the patient remains unknown $[26,28]$.

The literature is scarce in relation to other endodontic emergency situations in the current pandemic scenario, such as acute apical periodontitis and acute abscess. However, American researchers suggest that palliative pharmacological care is a good option and have demonstrated success in managing endodontic emergencies at a time when aerosol-generating procedures are restricted [22].

Not being sufficient to control pain, endodontic interventions should be performed. Swedish researchers [29] recently demonstrated in cases of localized symptomatic apical periodontitis that removal of necrotic and infected tissue from the pulp chamber might be a costeffective emergency treatment alternative to complete chemo-mechanical disinfection. In addition, the single file systems can be used in endodontic treatment as another alternative to decrease clinical time $[18,30]$ and avoid the risk of contamination during resterilization [2].

The post-care period must involve patient care and supervision, as well as environmental disinfection procedures [18]. Also, waste management must be carried out in a safe manner and must be conditioned in impermeable bags, made of material resistant to rupture and leakage, and placed in closed containers until collection by specialized services [18].

It is noteworthy that changes in biosafety protocols during the COVID-19 pandemic, the increase in PPE values, and the need to purchase new equipment such as thermometers have significantly increased the costs of dental treatments $[27,31]$.

\section{CONCLUDING REMARKS}

The main recommendations point out that endodontic care should only be performed in patients with clinical pain conditions. In cases of COVID-19 patients, the orientation is not to provide care in a primary dental environment, but in a hospital environment.

Dentists should focus not only on dental treatment and risk reduction, but also be aware of patients' psychological state. Further studies should be carried out using approaches to mitigate aerosol transmission and reduce the risks of COVID-19 contamination.

\section{Collaborators}

AL CAVALCANTI conceived the study. The paper was written by LHF FERNANDES, LMT BRANDT and AL CAVALCANTI.

\section{REFERENCES}

1. Zhu H, Fohlerova Z, Pekárek J, Basova E, Neužil P. Recent advances in lab-on-a-chip technologies for viral diagnosis. Biosens Bioelectron. 2020; 153(1):112041. https://doi. org/10.1016/j.bios.2020.112041

2. Yu J, Zhang T, Zhao D, Haapasolo M, Shen Y. Characteristics of endodontic emergencies during coronavirus disease 2019 outbreak in Wuhan. J Endod. 2020; 46(6):730-735. https:// doi.org/10.1016 / j.joen.2020.04.001

3. Lu B, Huang Y, Huang L, Li B, Zheng Z, Chen Z, et al. Effect of mucosal and systemic immunization with virus-like particles of severe acute respiratory syndrome coronavirus in mice. Immunology. 2010 Jun;130(2):254-61. https://doi. org/10.1111/j.1365-2567.2010.03231.x

4. Sharma S, Kumar V, Chawla A, Logani A. Rapid detection of SARS-CoV-2 in saliva: can an endodontist take the lead in point-of-care COVID-19 testing?. Int Endod J. 2020; 53(7):1017-1019. https://doi.org/10.1111/iej.13317

5. Sohrabi C, Alsafi Z, O’Neill N, Khan M, Kerwan Am, Al-Jabir A, et al. World Health Organization declares global emergency: a review of the 2019 novel coronavirus (COVID-19). Int J Surg. 2020; 76(1):71-76. https://doi.org/10.1016/j.jjsu.2020.02.034

6. American Dental Association. Coronavirus Center for Dentists 2020 [cited 2020 Jul 10]. Available from: <https://ada.org/>.

7. CDC. Centers for Disease Control and Prevention. Coronavirus Disease 2019 (COVID-19). Guidance for Dental Settings. 2020 [cited 2020 Jul 10]. Available from: <https://www.cdc. gov/coronavirus/>

8. Coulthard P. Dentistry and coronavirus (COVID-19) - Moral decision-making. Br Dent J. 2020; 228(7):503-505. https:// doi.org/10.1038/s41415-020-1482-1

9. van Doremalen N, Bushmaker T, Morris DH, Holbrook M, Gamble A, Williamson BN, et al. Aerosol and surface stability of SARS-CoV-2 as compared with SARS-CoV-1. N Engl J Med. 2020; 382(16):1564-1567. https://doi.org/10.1056/ NEJMc2004973

10. Bizzoca ME, Campisi G, Lo Muzio L. Covid-19 pandemic: what changes for dentists and oral medicine experts? A narrative 
review and novel approaches to infection containment. Int J Environ Res Public Health. 2020; 17(11):3793. https://doi. org/10.3390/ijerph17113793

11. Bai J, Xu T, Ai-Ping, Sun W, Huang MW. Impact of COVID-19 on oral emergency services. Int Dent J. 2020;10.1111/ idj.12603. https://doi.org/10.1111/idj.12603.

12. Ather A, Patel B, Ruparel NB, Diogenes A, Hargreaves KM. Coronavirus Disease 19 (COVID-19): Implications for clinical dental care. J Endod. 2020; 46(5):584-595. https://doi. org/10.1016/j.joen.2020.03.008

13. Maret D, Peters $O$, Vaysse F, Vigarios E. Integration of telemedicine into the public health response to COVID-19 must include dentists. Int Endod J. 2020; 53(6):880-881. https://doi.org/10.1111/iej.13312

14. Smith AC, Thomas E, Snoswell CL, Haydon H, Mehrotra A, Clemensen J, et al. Telehealth for global emergencies: implications for coronavirus disease 2019 (COVID-19). J Telemed Telecare. 2020; 26(5):309-313. https://doi. org/10.1177/1357633X20916567.

15. Umer F, Haji Z, Zafar K. Role of respirators in controlling the spread of novel coronavirus (COVID-19) amongst dental healthcare providers: a review. Int Endod J. 2020; 53(8):10621067. https://doi.org/10.1111/iej.13313

16. Yang $Y$, Soh H Y, Cai Z G, Peng X, Zhang Y, Guo CB. Experience of diagnosing and managing patients in oral maxillofacial surgery during the prevention and control period of the new coronavirus pneumonia. Chin J Dent Res. 2020; 23(1):57-62. https://doi.org/10.3290/j.cjdr.a44339

17. Prati C, Pelliccioni GA, Sambri V, Chersoni S, Gandolfi MG. COVID-19: its impact on dental schools in Italy, clinical problems in endodontic therapy and general considerations. Int Endod J. 2020; 53(5):723-725. https://doi.org/10.1111/ iej.13291

18. Amorim LM, Maske TT, Ferreira SH, Santos RB, Feldens CA, Kramer PF. New post-COVID-19 biosafety protocols in pediatric dentistry. Pesqui Bras Odontopediatri Clín Integr. 2020; 20(supp1):e0117. https://doi.org/10.1590/pboci.2020.117

19. Meng LY, Hua F, Bian Z. Coronavirus disease 2019 (COVID-19): Emerging and future challenges for dental and oral medicine. J Dent Res. 2020; 99(1):481-487. https://doi. org/10.1177/0022034520914246.

20. Chosewood L, Wilson D. Biosafety level criteria biosafety in microbiological and biomedical laboratories. 5th ed. Washington, 2009.

21. Fusco F, Puro V, Baka A, Bannister B, Brodt HR, Brouqui P, et al. Isolation rooms for highly infectious diseases: an inventory of capabilities in European countries. J Hosp Infect. 2009;73(1):15-23. https://doi.org/10.1016/j.jhin.2009.06.009
22. Patel B, Eskander MA, Ruparel NB. To drill or not to drill: management of endodontic emergencies and in-process patients during the COVID-19 pandemic. J Endod. 2020; S00992399(20)30605-1. https://doi.org/10.1016/j.joen.2020.08.008

23. Conselho Federal de Farmácia. Corona vírus: informações seguras, baseadas em evidências. 2020. Available from: https://www.cff.org.br/userfiles/Corona001\%20-\%20 16mar2020.pdf

24. Lamb LE, Bartolone SN, Ward E, Chancellor MB. Rapid detection of novel coronavirus (COVID-19) by reverse transcription-loop-mediated isothermal amplification. Plos One. 2020; 15(6):e0234682. https://doi.org/10.1371/journal. pone.0234682.

25. Yan C, Cui J, Huang L, Du B, Chen L, Xue G, et al. Rapid and visual detection of 2019 novel coronavirus (SARS-CoV-2) by a reverse transcription loop-mediated isothermal amplification assay. Clin Microbiol Infect. 2020; 26(6):773-779. https://doi. org/10.1016/j.cmi.2020.04.001.

26. Vandenberghe $B$, Jacobs $R$, Bosmans $H$. Modern dental imaging: a review of the current technology and clinical applications in dental practice. Eur Radiol. 2010; 20(11):2637-2655. https://doi.org/10.1007/s00330-010-1836-1

27. Kampf G, Todt D, Pfaender S, Steinmann E. Persistence of coronaviruses on inanimate surfaces and their inactivation with biocidal agentes. J Hosp Infec. 2020; 104(3): 246-251. https://doi.org/10.1016/j.jhin.2020.01.022

28. Samaranayake LP, Peiris $M$. Severe acute respiratory syndrome and dentistry: a retrospective view. J Am Dent Assoc. 2004; 135(9):1292-1302. https://doi.org/10.14219/jada. archive.2004.0405

29. Wolf E, Dragicevic M, Fuhrmann M. Alleviation of acute dental pain from localised apical periodontitis: A prospective randomised study comparing two emergency treatment procedures. J Oral Rehabil. 2019; 46(2):120-126. https://doi. org/10.1111/joor. 12730

30. Kuzekanani M. Nickel-titanium rotary instruments: development of the single-file systems. J Int Soc Prev Community Dent. 2018; 8(5):386-390. https://doi. org/10.4103/jispcd.JISPCD_225_18

31. Cavalcanti YW, Silva RO, Ferreira LF, Lucena EHG, Souza AMLB, Cavalcante DFB, et al. Economic Impact of New Biosafety Recommendations forDental Clinical Practice During COVID-19 Pandemic. Pesqui Bras Odontopiatria Clín Integ. 2020; 20(supp1):e0133. https://doi.org/10.1590/ pboci.2020.143

Received on: 10/8/2020

Final version resubmitted on: 22/10/2020

Approved on: 28/9/2020 